www.jmscr.igmpublication.org

Impact Factor 5.244

Index Copernicus Value: 83.27

ISSN (e)-2347-176x ISSN (p) 2455-0450

crossref DOI: _http://dx.doi.org/10.18535/jmscr/v4i8.72

\title{
Effects of Nesiritide in Patients with Acute Decompensated Heart Failure - A Review
}

\author{
Authors \\ Rohini.S ${ }^{1}$, T.A. Naufal Rizwan ${ }^{* 2}$ \\ ${ }^{1}$ Bachelor of Dental Surgery, Saveetha Dental College \& Hospital, Chennai, Tamil Nadu, India \\ ${ }^{2}$ Department of General Medicine, Saveetha Medical College \& Hospital, Chennai, Tamil Nadu, India \\ *Corresponding Author \\ T.A Naufal Rizwan \\ Department of General Medicine \\ Saveetha Medical College \& Hospital, Chennai, Tamil Nadu, India
}

\begin{abstract}
Acute decompensated heart failure is a major health problem that is associated with several million hospitalizations worldwide each year. ${ }^{[1]}$ In such patients, the predominant symptoms are dyspnea and fatigue which are associated with pulmonary venous congestion and low cardiac output. ${ }^{[2,3]}$ The primary goal of therapy is the rapid relief of these symptoms. Nesiritide, an intravenous (IV) form of human B-type natriuretic peptide is the first in a new pharmacologicclass of drug for treatment of decompensated congestive heart failure $(C H F)$. Nesiritide, a recombinant $B$ - type natriuretic peptide $(B N P)$ with vasodilatory properties, ${ }^{[4-7]}$ was approved in United States in 2001 for its use in patients with acute heart failure due to its ability to reduce pulmonary-capillary wedge pressure and improve dyspnea. Nesiritide is also well established as an agent for improving hemo dynamics in patients with acute heart failure. Compared with other agents used in treatment of acute decompensated heart failure $(A D H F)$, nesiritide is considered to be safer than inotropic agents such as dobutamine and milrinone. The ove all effects of nesiritide in patients associated with acute decompensated heart failure is reviewed.
\end{abstract}

KEY WORDS: Acute decompensated heart failure, Dobutamine, Hemodynamics, Milrinone, \& Nesiritide.

\section{INTRODUCTION}

Heart failure (HF) is a major and growing public health concern, significant lyimpairing quality of life and reducing years of age and is a primary hospital discharge diagnosis in approximately 1 million people of all ages each year. [8,9] Symptomatic decompensation is the most common reason for the hospitalization of patients with congestive heart failure due to left ventricular systolic dysfunction. In such patients, the predominant symptoms dyspnea and fatigue are associated with pulmonary venous congestion and low cardiac output. Accordingly, the primary goal of treatment, which is the rapid relief of symptoms, is usually approached with the use of intravenous diuretics, vasodilators, and positive inotropic agents to decrease cardiac filling pressures and increase cardiac output. Dobutamine is a widely used inotropic therapy for decompensated heart failure. Although 
dobutamine can cause earlyhemodynamic and symptomatic benefits, its use is limited by potentially serious side effects such as tachycardia, hypotension, myocardial ischemia and cardiac arrhythmias. ${ }^{[10-13]}$

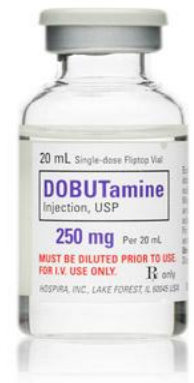

Fig 1: Dobutamine

Generally it has been assumed that improved hemodynamic function will resultin the resolution of symptoms in patients with decompensated congestive heart failure, most studies of new drugs for this purpose have focused on hemodynamic, rather than symptomatic, end points. One of such newer drug isthe Nesiritide. Intravenous infusion of nesiritide, a brain (B-type) natriuretic peptide, has beneficial hemodynamic effects in patients with decompensated congestive heart failure. Brain (B-type) natriuretic peptide is synthesized in the ventricular myocardium, where its levels increase in patients with congestive heart failure. ${ }^{[14,15]}$ Systemic infusion of nesiritide, a recombinant human brain natriuretic peptide, in patients with congestive heart failure results in beneficial hemodynamic actions, including arterial and venous dilatation, enhanced sodiumexcretion, and suppression of the renin-angiotensinaldosterone and sympathetic nervous systems.

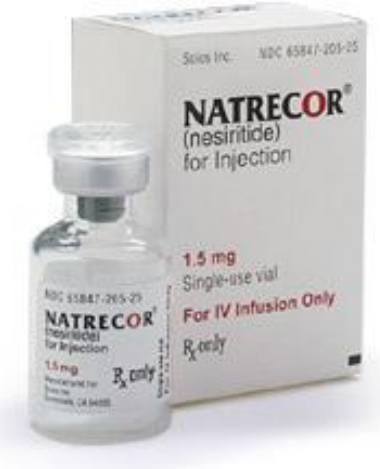

Fig 2: Nesiritide
EFFECTS OF NESIRITIDE IN ACUTE DECOMPENSATEDHEART FAILURE

The infusion of nesiritide in patients with decompensated congestive heart failure resulted in improvements in hemodynamic function and rapid and sustained improvements in clinical status. Many studies demonstrate that nesiritide relieves the symptoms of decompensated congestive heart failure. When compared with standard therapy consisting primarily of dobutamine or milrinone. ${ }^{[16]}$ Nesiritide causes a dose-related decrease in pulmonary-capillary wedge pressure. This effect was associated with a decrease in systemic vascular resistance and an increase in the cardiac index. Since nesiritide exerts no direct, positive inotropic action on the myocardium, the increase in cardiac output presumably reflects a reduction in left ventricular after load. [17] After six hours, the decrease in systemic vascular resistance was associated with mean decreasesin systolic blood pressure. The decrease in blood pressure was not associatedwith reflex tachycardia or an increase in plasma norepinephrine levels. ${ }^{[18,}$ 19] The observations made from various studies suggest that nesiritide may behelpful in the clinical management of fluid overload in patients with congestive heart failure. The most common adverse effect of nesiritide is dose-dependent hypotension, which is usually asymptomatic or associated with only mildsymptoms. ${ }^{[20]}$ The salutary clinical and hemodynamic profile of nesiritide and the relative absence of adverse effects associated with it circumvent several of these limitations.

\section{EFFECTS OF NESIRITIDE ON RENAL FUNCTION}

One of the main challenges in the treatment of acute decompensated heart failure (ADHF) is worsened renal function. Renal dysfunction independently predicts a worse outcome in heart failure in general and ADHF in particular. Renal dysfunction is a strong predictor of long-term risk in cardiovascular health as well as worsening of clinical outcome during hospitalization. [20-22] 
Although the primary mechanism of action of nesiritide is systemic and pulmonary vasodilator, it has multiple effects on the kidneys, including promoting natriuretic, diuresis, and inhibiting the renin-angiotensin aldosterone axis. ${ }^{\text {[23-25] }}$

Patients taking nesiritide do developed significantly lower systolicand diastolic blood pressure, despite this lower blood pressure, patients onnesiritide did not develop worsened renal dysfunction. A possible reason maybe the balance of "direct" and "indirect" effects of natriuretic peptides on renal function. ${ }^{[24]}$ Direct effects of natriuretic peptides serve to increase GFR by relaxing renal mesangial cells, dilating the afferent renal arteriole, and constricting the efferent renal arteriole; indirect effects serve to decrease GFR by inhibiting the renin-angiotensinaldosterone and sympathetic axes and by lowering systemic blood pressures and circulating blood volume. It is likely the balance of these direct and indirect effects that causes GFR to increase, decrease, or stay the same in individual patients. ${ }^{[25]}$ Most of the studies have reported that $28 \%$ of patients developed worsening renal function during heart failure hospitalization, which they defined as anincrease in serum creatinine of 0.3 $\mathrm{mg} / \mathrm{dL}$. Patients with worsening renal function were at increased risk of death. ${ }^{[26]}$ Further studies have also found the direct association between duration of nesiritide infusion and a rise in Serum Creatinine (SCr) or Blood urea nitrogen (BUN) in patients with ADHF. Worsening of renal function was significantly associated with duration of infusion 24 hours or more compared with less than 24 hours. Additionally, the incidence of $\mathrm{SCr}$ and BUN elevations was found to be highest in the 36 hour or more infusion group compared with the groups with shorter infusion duration. Shorter duration of infusion $(<24 \mathrm{~h}$ ) was not found to be associated with significant elevations of $\mathrm{SCr}$ and BUN, compared with longer infusion duration. Nesiritide infusion of 24 hours or more is associated with an increased risk of worsening surrogate markers of renal function in patients with ADHF compared with infusions of less than 24 hours. ${ }^{[27]}$

\section{CONCLUSION}

Nesiritide is widely used, largely because of its prompt improvement of pulmonary capillary wedge pressure and symptoms. ${ }^{[28]}$ In the current analysis of data rates of in-hospital mortality in patients treated with nesiritide were similar to those in patients treated with nitroglycerin, and nesiritide or nitroglycerin were associated with a significant survival benefit compared with either dobutamine or milrinone. ${ }^{[29]}$ These mortality data support the use of nitroglycerin or nesiritide rather than positive inotropic agents in the management of patients with ADHF who require IV vasoactive therapy. Positive inotropic agents should be considered only in patients who are refractory to treatment with vasodilators or nesiritide or in patients in impending cardiogenic shock. We therefore suggest that nesiritide would be a valuable addition to the initial treatment of patients admitted to the hospital ford compensated congestive heart failure. ${ }^{[30]}$

\section{REFERENCES}

1. Lloyd-Jones D, Adams RJ, Brown TM, et al. Heart disease and strokestatistics 2010 update: a report from the American Heart Association. Circulation 2010; 121(7):e46-e215.

2. Nieminen MS, Brutsaert D, Dickstein K, et al. EuroHeart FailureSurvey II (EHFS II): a survey on hospitalized acute heart failure patients: description of population. Eur Heart J 2006;27:2725-36.

3. Bueno H, Ross JS, Wang Y, et al. Trends in length of stay andshort-term outcomes among Medicare patients hospitalized for heart failure,1993-2006. JAMA 2010; 303:2141-7.

4. Clarkson PB, Wheeldon NM, Macleod C, Coutie W, MacDonald TM.Brain natriuretic peptide: effect on left 
ventricular filling patterns inhealthy subjects. ClinSci (Lond) 1995;88:159-64.

5. Colucci WS, Elkayam U, Horton DP, et al. Intravenous nesiritide, anatriuretic peptide, in the treatment of decompensated congestive heartfailure. $\mathrm{N}$ Engl J Med 2000;343:246-53. [Errata, N Engl J Med2000;343:896, 1504.]

6. Intravenous nesiritide vs nitroglycerin for treatment of decompensatedcongestive heart failure: a randomized controlled trial. JAMA2002;287:1531-40. [Erratum, JAMA 2002;288:577.]

7. Zellner C, Protter AA, Ko E, et al. Coronary vasodilator effects ofBNP: mechanisms of action in coronary conductance and resistance arteries. Am J Physiol 1999; 276:H1049-57.

8. American Heart Association, American Stroke Association. Heart Diseaseand Stroke Statistics-2005 Update. Available at: p://www.americanheart.org/downloaddable/heart/1105390918119HDSStats2005 Update.pdf.Accessed January 13, 2005.

9. Krumholz HM, Parent EM, Tu N, et al. Readmission after hospitalization forcongestive heart failure among Medicare beneficiaries. Arch Intern Med1997;157:99-104.

10. Packer M, Carver JR, Rodeheffer RJ, et al. Effect of oral milrinone onmortality in severe chronic heart failure: The PROMISE Study Research Group.N Engl J Med 1991;325:1468-75

11. Massie BM, Berk MR, Brozena SC, et al. Can further benefitbe achieved byadding flosequinan to patients with congestive heart failure who remainsymptomatic on diuretic, digoxin, and an angiotensin converting enzymeinhibitor? Results of the Flosequinan-ACE inhibitor Trial (FACET). Circulation1993;88:492-501.

12. Packer M, Narahara KA, Elkayam U, et al. Double-blind, placebocontrolledstudy of the efficacy of flosequinan in patients with chronic heart failure. Principal Investigators of the REFLECT Study. J Am CollCardiol 1993;22:65-72.

13. Moe GW, Rouleau JL, Charbonneau L, et al. Neurohormonal activation insevere heart failure: relations to patient death and the effect of treatment with flosequinan. Am Heart J 2000;139:587-95.

14. Joffee MM, Rosenbaum PR. Invited commentary: propensity scores. Am JEpidemiol 1999;150:327-33.

15. Rubin DB. Estimating causal effects from large data sets using propensityscores. Ann Intern Med 1997;127:757-63.

16. Colucci WS, Packer M, Bristow MR, et al. Carvedilol inhibits clinicalprogression in patients with mild symptoms of heart failure. Circulation1996;94:2800-6.

17. Tisdale JE, Patel R, Webb CR, Borzak S, Zarowitz BJ. Electrophysiologic and proarrhythmic effects of intravenous inotropicagents. Prog Cardiovasc Dis 1995;38:167-80.

18. Anderson JL, Askins JC, Gilbert EM, Menlove RL, Lutz JR.Occurrence of ventricular arrhythmias in patients receiving acute andchronic infusions of milrinone. Am Heart J 1986;111:466-74.

19. Packer M, Lee WH, Kessler PD, Gottlieb SS, Medina N, Yushak M.Prevention and reversal of nitrate tolerance in patients with congestiveheart failure. N Engl J Med 1987;317:799-804.

20. Braunwald E, Colucci WS, Grossman W. Clinical aspects of heartfailure. In: Braunwald E, ed. Heart disease: a textbook of cardiovascularmedicine. 5th ed. Vol. 1. Philadelphia: W.B. Saunders, 1997:445-70

21. VanKimmenade RR, Januzzi JL, Baggish AL, et al. Amino-terminal probrainnatriuretic peptide, renal function, and outcomes in acute heart failure:redefining the cardiorenal interaction? J Am CollCardiol 2006;48:1621-7. 
22. Mahan NG, Blackstone EH, Francis GS, Starling RC III, Young JB, LauerMS. The prognostic value of estimated creatinine clearance alongside functionalcapacity in patients with chronic congestive heart failure. J Am Coll Cardiol2002;40:110613.

23. Marcus LS, Hart D, Packer M, et al. Hemodynamic and renal excretoryeffects of human brain natriuretic peptide infusion in patients with congestiveheart failure. Circulation 1996;94:3184-9.

24. DeLemos JA, McGuire DK, Drazner MH.B-type natriuretic peptide incardiovascular disease. Lancet 2003;362:316-22.

25. Aronson D, Burger AJ, Cleland JG, et al. Nesiritide: a review of its use inacute decompensated heart failure. Drugs 2003;63:47-70.

26. Chertow GM, Levy EM, Hammermeister KE, Grover F, Daley J.Independent association between acute renal failure and mortality followingcardiac surgery. Am J Med. 1998;104:343-348.

27. Yancy CW, Saltzberg MT, Berkowitz RL, et al. Safety and feasibility ofusing serial infusions of nesiritide for heart failure in an outpatient setting (fromthe FUSION I Trial). Am J Cardiol 2004;94:595- 601

28. Abraham WT, Lowes BD, Ferguson DA, Odom J, Kim JK, Robertson AD,Bristow MR, Schrier RW.Systemic hemodynamic, neurohormonal, and renaleffects of a steady-state infusion of human brain natriuretic peptide in patientswith hemodynamically decompensated heart failure. J Card Fail. 1998;4:37-44.

29. Mills RM, LeJemtel TH, Horton DP, Liang C, Lang R, Silver MA, Lui C,Chatterjee K. Sustained hemodynamic effects of an infusion of nesiritide(human b-type natriuretic peptide) in heart failure: a randomized, doubleblind,placebocontrolled clinical trial: Natrecor Study
Group. J Am CollCardiol.1999;34:155162

30. Stevenson LW, Colucci WS. Management of patients hospitalized with heart failure. In: Smith TW, ed. Cardiovascular therapeutics. Philadelphia:W.B. Saunders, 1996:199-209. 